\title{
THE DEVELOPMENT OF CARTOGRAPHY \\ IN THE REPUBLIC OF MACEDONIA
}

DOI: http://dx.doi.org/10.18509/GBP.2016.27

UDC: 528.9-043.86(497.7)

\author{
Blagoja Markoski, PhD \\ University "Ss. Cyril and Methodius ", Faculty of Natural Sciences and Mathemathics, \\ Institute of Geography - Skopje
}

\begin{abstract}
The aim of this scientific paper is the development of cartography within Macedonia and regarding Macedonia. Comprised here, are subjects relating to geography and the historical location of Macedonia throughout the ages, during the time of the Balkan wars and the cartographical demonstrations, especially those after the great geographical discoveries. In addition, particular attention is devoted to the appearance of the first topographical maps of the territory of Macedonia and in that sense the organization and production of these maps which is primarily under the jurisdiction of the VGI and Belgrade. Besides the stated topics, a short summary of the development of cartography in Macedonia as an educational and scientific discipline and her treatment within the specialized geodesic and cartographic institutions is also provided.

The contribution of this article is to elaborate further into the historical cartography as a separate field in cartography as well as in the sense to supplement the history, tradition and culture of Macedonia in the sphere of this segment.
\end{abstract}

Keywords: cartography, cartographic presentation, topographic maps, gradus measurements, cartographic european schools, geographic discoveries

\section{THE GEOGRAPHICAL LOCATION OF THE REPUBLIC OF MACEDONIA}

The territory located between the dried up Pazarsko lake and the lower reaches of Vardar with the capital Pela, was called Macedonia. The new territories conquered by the macedonian kings were naturally called Macedonia. During the time of Philip II and Alexander III of Macedon (356-323), Macedonia has expanded to include three continents but the name remained to refer to the homeland which today mean the territories composed of catchment flows of Mesta, the river basin of Struma, from the now known Blagoevgrad to the infusion, the Vardar basin, the upper basin of Crni Drim with lake Ohrid and lake Prespa and the river basin of Bistrita. This name continued to exist during the Roman empire as well as today. With this territory of $67741 \mathrm{~km}^{2}$ also are equated the ethical boundaries of Macedonia which existed until 1913 (with the Balkan wars she is divided so that $51 \%$ of the territory is annexed by Greece, $38 \%$ annexed by Serbia, $10 \%$ by Bulgaria and $1 \%$ by Albania) [2]. The land which became annexed by Serbia after the Second world war managed to gain status as an independent republic which geographically encompases the central region of the Balkan peninsula with overall surface of $25713 \mathrm{~km}^{2}$ and 2,000,000 citizens. 


\section{MACEDONIA THROUGHOUT THE AGES}

Macedonia's achievements during the time of Philip II and his son Alexander III are closely correlated to that of the most developed civilizations (Persia and Mesopotamia, the Egyptian culture, Greek culture, the accomplishments of the Phoenicians, the development of the Roman empire etc.) in that time, on the other hand, is the main reason for the ongoing cartographical demonstration of Macedonia on the maps during this time period. As most famously preserved maps on which the territories of Macedonia are displayed are the Tabula Peutingeriana (IV century), the map of Beatus (776), the map of the world called Cottoniana (X century), the map of the world by Matthaeus Parisiensis (XII century) and other maps [7] created in principle of a circular or elliptic form.

During the Middle Ages characterized with the general cessation of science and culture in this case in Macedonia as well. Even afterwards, after the Great geographical discoveries nearing the end of the 15th century and the beginning of the 16th, starts the general development of cartography, and in that sense the production of maps on which the surface of Macedonia is displayed.

The discovery and print of Ptolemy's book in the middle of the 15th century and the print of Ptolemy's map in 1477 (which is considered to be the first year of map printing) is regarded as the first map on which the territories of Macedonia are presented. The always present geostrategic positioning of the Balkan, and in that context that of Macedonia's (because of the proximity to the Aegean Sea and the other seas in the Mediterranean), is the reason which numerous authors in European cartography school create maps on which presented is also the territory of Macedonia (separately or as part of bigger territories). By different standards, today these maps are kept in national libraries such as in France, the United Kingdom, Russia, Austria and other countries. As most characteristic are the maps of: C.Ptolomaios (1477), Castorius (Tabula Peutingeriana), Piri Reis (1521), G. Gastaldi (1560), G. Merkator (1589), I. laurenbergio (1647), G. Canteli da Vignola (1689), N. Sanson (1696), G. De L'Isle (1707), J. Harenberg (1741), S. Janvier (1750), V. Robert (1775), P. Lapie (1810), J. Cary (1811), A. Lapie (1822 и 1843), G. Moller (1828), D. Seljan (1847) and numerous other maps [7].

As the first map by a Macedonian is considered to be the map of Macedonia following the program of the Macedonian nationalists, the first map was created by Dimitrie Cupovski in Petrovgrad 1913 with a map proportion of 1:1000000 and dimensions $62 \mathrm{x}$ 37 centimeters [8]. The map is featured before the "great powers" as proof of the significance of the Macedonian territory, culture and tradition before the separation governed by the Balkan countries.

\section{MACEDONIA FEATURED ON TOPOGRAPHIC MAPS}

The degree measurements and the positioning of the triangular net in France in the 17th century represents a new epoch of progress and development of the cartographical achievements in the world. They quickly spread to other countries, and with that, to the Balkan as well, that is, within the borders of the Ottoman empire. Called upon or sent professionals (because of different purposes) from France, Austria-Hungary and Russia begin to design maps with a more modern approach, and in that sense, begins another measuring of the land of Macedonia in the second half of the 14th century [6]. With these activities, besides the other general geographical maps in 1900, are also features the first ever topographical maps of the territory of Macedonia with proportion of 1:200000 designed by Austria-Hungary, and a map with scale of 1:210000 designed by Turkey [6]. 
Based on these cartographical sources and the posed topographic example of the geographic department of the main staff of the serbian army (founded in 1878) directly before the Balkan wars is designed a topographic map of Serbia and Macedonia [10] with a scale of 1:150000. After the territorial division of Macedonia in 1913 cartographical activities regarding the territory of today's Republic of Macedonia were under the authority of the topographic department under sovereign command of the Serbian army until 1920, afterwards under the geographic institute in Belgrade.

With regards to the general equality of the Republic of Macedonia in frame of the then present country of Yugoslavia after the Second world war, by the Military geographic institute of Belgrade were designed topographic maps with scale between 1:25000, 1:50000, 1:100000 and 1:200000 etc. [1] These maps, in accompaniment with the use of decently modern technique and technology for the manufacturing exhibited a high degree of accuracy and world-class cartographic standards.

Consciously or not, not foretelling any negative development of the events of the then present Yugoslavia, the Republic of Macedonia after the Second world war did not create an independant cartographical institution which's main affiliation would be the general production of maps. The reason for this situation on this plan might be that of diverse nature, but without those regards, the Republic of Macedonia within the domain of independant cartographic production in this aforementioned time period remained handicapped on this objective.

\section{CARTOGRAPHY IN THE LINES OF SCIENTIFIC AND PROFESSIONAL INSTITUTIONS IN THE REPUBLIC OF MACEDONIA}

As a necessity after the Second world war in the Republic of Macedonia in the field of education of this branch are formed the Institute of geography and the group for geodesy within the Faculty of Civil Engineering in Skopje from one and in service of the state because of taxation needs is formed the then-present Republic geodetic management with the Office of Aerophotogrammetry (now knows as the Agency of cadastre and real estate).

Immediately after the Second world war within the Faculty of Philosophy (december 1946) as one of the first institutions is formed the first geographic department which today holds rank as the institute of geography within the Faculty of Natural sciences and mathematics in Skopje.

From the very beginning, the geography department, in its curriculum and program cartography exists as a separate study with a tendency of permanent promotion of its educational and scientific content [4,5]. In 1992 the first ever PhD student defended his dissertation regarding certain problems in geography. Nearing the end of the nineties of the 20th century, the Institute of geography made available postgraduate studies in cartography, which later on were promoted to postgraduate studies in Geographical Informational systems.

In 1977/78 in the field of education begins with the work of the Institute of geodesy within the Faculty of Civil Engineering [3] where in the curriculum and program is present mathematical cartography.

Because of the unavoidable management and organization of the cadastre of the land of the Republic of Macedonia, immediately after the Second World War the Republic geodetic administration was formed. In this institution the main scope of work consisted of the preparation of topographic plans, stereo-constitucional treatment of 
aerophotographs, keeping records of the land according to cadastral cultures and creditworthiness, inspectional work within the cadastres in municipalities and other activities. After 2005 in this institution (named now as Agency of cadastre and real estate) began development and production of topographic maps with proportions between $1: 25000$ and $1: 50000$.

\section{THE CARTOGRAPHY IN THE SCIENTIFIC AND PROFESSIONAL JOURNAL IN THE REPUBLIC OF MACEDONIA}

Within reference to the aforementioned educational and scientific institutes, the problems from the field of cartography are treated through numerous professional and scientific papers by different authors [9]. They are mainly presented in the following journals: Geographical Reviews, Annual Proceedings and Geodetic examination.

In the journal Geographical Reviews in 48 editions are published around 50 papers with cartographic or similar content. In the Annual Proceedings there are no geographical papers, but that is why, within this journal are moved an array of thematic maps with different contents. The Geodetic examination mainly treats topics regarding the field of geodesy, but with the tight correlation between this discipline with that of cartography the presented papers hold remarkable importance for the discipline of geodesy as well.

In a kind of contribution to the papers in the different journal are published a great number of historical and above all thematic maps.

Besides the aforementioned, of importance to mention is that the Republic of Macedonia even though does not affiliate with the immanent production of maps by different bases, it has also formed a certain fund of cartographic materials which are most frequently discerned in the National and National and University Library "St. Kliment Ohridski" in the Republic of Macedonia where there is a compilation of about 6000 maps, in the Institute of geography in the Faculty of Natural sciences and mathematics in Skopje [5] in the Republic geodetic management and at numerous other institutions (cadastres, military services, museums, smaller urban and educational libraries) and individuals.

With the forming of the Republic of Macedonia as an independent and self-governing state certain activities for organizing a separate cartographic productions were taken, so that, that activity was taken under the jurisdiction of the Agency of cadastre and real estate and today the cartographical production of topographics, plans and maps is in the competence of this institution. In context to the privately-owned cartographic production, especially orientated towards thematic cartographic production in the Republic of Macedonia, also exist private companies such as Trimaks - cartography, Geomap DOO and other firms where this activity is supported [5].

The overall activity with the reevaluation, inventorization, construction, reduction, modification and production of the maps is mainly managed and realized in Macedonian institutions, with Macedonian cartographic staff potential. In this sense, with the introduction of computerized techniques and technology in tandem with modern reaches in the field of cartography in the world and in the Republic of Macedonia there are already present the newest techniques and technologies for electronic cartographical production [5]. 


\section{CONCLUSION}

The consideration of the development of the cartography in the Republic of Macedonia is with a goal to see to the cartographic treatment of its territory in history. Besides that, demonstrated are cartographic activities which are developed in newer times with a goal of producing topographic maps. It is constituted that because of the geostrategic location of the territory of the Republic of Macedonia is also demonstrated on a bigger number of maps. Because of the same reasons numerous number of authors are called upon or sent out to work on the geodesic reevaluation of the land and the production of maps. It is also constituted that that in this century the inferences in relation to the cartographic problematics in the Republic of Macedonia are held by the Military-geographic institute in Belgrade. But, with the achievement of the independence the Republic of Macedonia in lines of the educational institutions (the Institute for Geography in the Faculty of Natural sciences and mathematics, the Department of geodesy within the Faculty of Civil Engineering) a professional staff was formed in the field of cartography and a cartographic production in the Agency of cadastre and real estate was organized as well as in Trimaks - cartography, Geomap DOO and other firms.

\section{REFERENCES}

[1] The Military Geographical Institute, (1984): Editorial report, Forty years of The Military Geographical Institute work and development in socialist Yugoslavia, Beograd.

[2] INI, (1978): Macedonia as natural and economic unit, Skopje.

[3] Lazarov D., (1989): Schooling surveying staff in SR Macedonia, Surveying review, book. 31-35, Skopje.

[4] Markoski B., (2003): Cartography, Geomap, Skopje.

[5] Markoski B.: Own research and materials.

[6] Peterca M. i dr. (1974): Cartography, The Military Geographical Institute, Beograd.

[7] Petrushevski I., (1992): Macedonia at old maps, Skopje.

[8] National and University Library "St. Kliment of Ohrid", (1987): Macedonia on maps. Special bibliography 1, Skopje.

[9] Stojmilov A., (1986): Forty years higher educational and scientific research at the Institute of Geography, Faculty of Natural Sciences and Mathematics, Yearbook, vol. 30, Skopje.

[10] Cholovic G., (1984): Geodetic and cartographic activities in the Serbian army until unification of Yugoslav countries in 1918. 